\title{
Anemia and iron homeostasis in a cohort of HIV- infected patients in Indonesia
}

Rudi Wisaksana ${ }^{1,2^{*}}$, Rachmat Sumantri ${ }^{1}$, Agnes R Indrati ${ }^{2,3}$, Aleta Zwitser ${ }^{4}$, Hadi Jusuf ${ }^{1}$, Quirijn de Mast ${ }^{4}$, Reinout van Crevel $^{2,4}$ and Andre van der Ven ${ }^{4}$

\begin{abstract}
Background: Anemia is a common clinical finding in HIV-infected patients and iron deficiency or redistribution may contribute to the development of low hemoglobin levels. Iron overload is associated with a poor prognosis in HIV and Hepatitis C virus infections. Iron redistribution may be caused by inflammation but possibly also by hepatitis C co-infection. We examined the prevalence of anemia and its relation to mortality in a cohort of HIV patients in a setting where injecting drug use (IDU) is a main mode of HIV transmission, and measured serum ferritin and STfR, in relation to anemia, inflammation, stage of HIV disease, ART and HCV infection.

Methods: Patient characteristics, ART history and iron parameters were recorded from adult HIV patients presenting between September 2007 and August 2009 in the referral hospital for West Java, Indonesia. KaplanMeier estimates and Cox's regression were used to assess factors affecting survival. Logistic regression was used to identity parameters associated with high ferritin concentrations.

Results: Anemia was found in 49.6\% of 611 ART-naïve patients, with mild (Hb 10.5 - $12.99 \mathrm{~g} / \mathrm{dL}$ for men; and 10.5 $11.99 \mathrm{~g} / \mathrm{dL}$ for women) anemia in $62.0 \%$, and moderate to severe anemia ( $\mathrm{Hb}<10.5 \mathrm{~g} / \mathrm{dL}$ ) in 38.0\%. Anemia remained an independent factor associated with death, also after adjustment for CD4 count and ART ( $p=0.008$ ). Seroprevalence of HCV did not differ in patients with (56.9\%) or without anemia (59.6\%). Serum ferritin concentrations were elevated, especially in patients with anemia $(p=0.07)$ and/or low CD4 counts $(p<0.001)$, and were not related to hsCRP or HCV infection. Soluble TfR concentrations were low and not related to Hb, CD4, hsCRP or ART.
\end{abstract}

Conclusion: HIV-associated anemia is common among HIV-infected patients in Indonesia and strongly related to mortality. High ferritin with low STfR levels suggest that iron redistribution and low erythropoietic activity, rather than iron deficiency, contribute to anemia. Serum ferritin and sTfR should be used cautiously to assess iron status in patients with advanced HIV infection.

Keywords: anemia, iron, HIV

\section{Background}

Anemia is a common clinical finding in HIV-infected patients and is associated with advanced disease, lower quality of life and higher mortality [1-4]. Many factors may contribute to the development of anemia in HIVinfected patients including nutritional deficiencies, opportunistic infections, AIDS-related malignancies, drug treatment and a direct effect of HIV on the bone

\footnotetext{
* Correspondence: rudiw98@gmail.com

'Department of Internal Medicine Faculty of Medicine, Padjadjaran

University/Hasan Sadikin Hospital, Bandung, Indonesia

Full list of author information is available at the end of the article
}

marrow [4]. Iron deficiency and inflammation-induced iron maldistribution may also contribute to HIV-associated anemia $[5,6]$. Due to the effects of inflammation, iron is diverted from the circulation into the reticuloendothelial system and other storage sites. Apart from inflammation, also $\mathrm{HCV}$ may possibly contribute to redistribution of iron [7]. Hepcidin plays an important role in these processes $[8,9]$, by limiting the availability of iron for hematopoiesis [10]. Iron maldistribution may have another unwanted effect; it may increase susceptibility to opportunistic infections, and accelerate disease progression [7,11-14]. Indeed, iron overload is associated

\section{Biomed Central}


with a poor prognosis in HIV and Hepatitis $\mathrm{C}$ virus infections [7].

Serum concentrations of ferritin and soluble transferrin receptor (sTfR) are frequently used to assess iron status [15]. Low ferritin is an indicator of iron deficiency, but as ferritin is also an acute phase reactant its interpretation is difficult in the presence of inflammation. Levels of sTfR are predominantly determined by the erythropoietic activity. Iron deficiency leads to increased erythroblast numbers and increased TfR expression and thus to considerably elevated sTfR levels. In contrast, anemia of inflammation is characterized by normal sTfR levels $[6,16]$.

So far, limited and sometimes contradictory reports have been published on ferritin and STfR in HIVinfected patients. High plasma ferritin concentrations have been found among HIV-infected patients [14,17-19], while other studies have reported low ferritin concentrations [20,21]. Co-infection with hepatitis C virus $(\mathrm{HCV})$ may further complicate the assessment of iron status, as HCV infection is associated with high plasma ferritin concentrations [22]. With respect to sTfR levels in HIV patients, two studies found sTfR within the normal range $[14,18]$, suggesting that sTfR is not affected by HIV infection [12]. However, this is in contrast with two other studies showing an increase in sTfR concentrations after initiation of antiretroviral treatment (ART) [19,21].

In the present study, we examined the prevalence of anemia and its relation to mortality in a cohort of HIV patients in a setting where injecting drug use (IDU) is the main mode of HIV and HCV transmission [23]. We also measured serum ferritin and sTfR, in relation to anemia, inflammation, stage of HIV disease, ART and $\mathrm{HCV}$ infection.

\section{Methods}

\section{Setting and design}

This cohort study was conducted at Hasan Sadikin hospital as the referral hospital for HIV in West Java, Indonesia. As one of the first 25 hospitals selected by the Indonesian government to provide HIV-care, Hasan Sadikin hospital has delivered free antiretroviral treatment and PCP-prophylaxis since December 2004. Following WHO and national guidelines [24,25], ART is indicated for patients presenting with WHO clinical stage IV, WHO clinical stage III with a CD4 count below $350 / \mathrm{mm}^{3}$, or WHO clinical stage I or II with a CD4 count below $200 / \mathrm{mm}^{3}$. The national program provides a choice of nevirapine (NVP), efavirenz (EFV), zidovudine (ZDV), stavudine ( $\mathrm{d} 4 \mathrm{~T})$ and lamivudine (3TC) as first-line ART. For this study, we included all HIV-positive patients above 14 years old presenting between September 2007 and August 2009. All patients signed informed consent and the study was approved by the hospital ethical committee.

\section{Data collection and laboratory examination}

At time of first presentation at the hospital, all patients (both ART-naïve and ART-experienced) have a 'baseline visit' for structured interviewed and laboratory examination. Afterwards they come for scheduled visits, oncemonthly when on ART, three- to six-monthly when not on ART. ART naïve patients were compared with patients with a favorable effect of ART, excluding those that with less than three months of ART, those who had ever interrupted ART for more than one month, those who had detectable HIV-RNA after six months ART, and those taking $2^{\text {nd }}$ ART. At presentation, data collected included gender, age, history of injecting drug use, body mass index (BMI, $\left.\mathrm{kg} / \mathrm{m}^{2}\right)$, WHO stage, oral candidiasis, and history of ART or tuberculosis (TB) treatment. For ART-experienced patients, treatment duration and regimen were recorded. During follow-up, death was recorded from medical records.

Laboratory examinations included hemoglobin, red cell indices (Cell Dyne 3000, Abbot) and manual reticulocyte counts. Reticulocyte index was defined as the reticulocyte percentage $\times$ (measured hematocrit/normal hematocrit) [26]. Anti HCV antibodies were detected by an electrochemiluminescence assay, ECLIA (Elecsys 2010, Roche) and CD4-cell count by flowcytometry (BD Biosciences, Jakarta, Indonesia). In our setting, HIVRNA (real time PCR, Abbott, USA) is only measured in patients taking ART, but not in ART naïve patients. Between January 2008 and June 2008 we also measured plasma ferritin (ECLIA method Elecsys 2010, Roche; reference range 30-400 ng/mL for men and 35-150 ng/ $\mathrm{mL}$ for women), soluble Transferin Receptor (sTfR) (enzyme Immunoassay method, Diamed, Eurogen; reference range 1870-2450 U/mL) and high sensitive C-Reactive Protein (hsCRP) (immunoturbidimetry method, Hitachi 912, Roche; reference $<5 \mathrm{mg} / \mathrm{L}$ ) in newly diagnosed patients. We defined ferritin as 'high' if it was above the upper reference value.

\section{Data analysis and statistics}

WHO/ACTG criteria were used to define mild (Hb 10.5 $12.99 \mathrm{~g} / \mathrm{dL}$ for men; and $10.5-11.99 \mathrm{~g} / \mathrm{dL}$ for women), moderate $(\mathrm{Hb} 8.0-10.49 \mathrm{~g} / \mathrm{dL})$ and severe $(\mathrm{Hb}<8.0 \mathrm{~g} /$ $\mathrm{dL})$ anemia $[27,28]$. As diagnosis of TB is difficult in HIVpositive patients in this setting due to its paucibacillary nature and the fact that many patients are unable to expectorate sputum [29], we considered all patients receiving $\mathrm{TB}$ treatment within three months after presentation as having TB co-infection. Mortality data were derived from clinical files, reports from community organizations or phone interviews from the clinic. Patients not returning 
for more than three months without confirmation of death or transfer were considered lost to follow-up. Data are presented as proportions or median with inter quartile range if not normally distributed. Categorical and continuous data were compared using the Chi-squared and Kruskal-Wallis tests respectively. Progression to death was measured by Kaplan-Meier estimates with Cox-regression to examine factors in baseline visits that affecting survival. Ferritin and STfR concentration divided based on manufacturers reference values. Cox-proportional hazard regression model was used to investigate association between iron inflammatory parameters and mortality. Clinical parameters were examined as a possible determinant of mortality and high ferritin concentrations using logistic regression models. Variables which were significantly associated in univariate analysis $(p<0.05)$ were used in the final backward stepwise multivariate regression model. Proportionality was first assessed by generating time dependent covariates of interactions between predictors and survival function. Log-transformed ferritin and sTfR values were used to examine the relation between ferritin, sTfR, CRP and CD4. All statistical analysis was done using SPSS version 16.0.2 and Prism 4 for Windows.

\section{Results}

\section{Patient characteristics}

A total number of $869 \mathrm{HIV}$ positive patients were enrolled in this study, 70.3\% (611) of whom were ART naïve, and 258 (29.7\%) of whom were on ART (Figure 1). Table 1 shows the baseline patient characteristics.

\section{ART naïve patients}

In this group, mild, moderate and severe anemia was present in $30.4 \%, 14.1 \%$, and $4.6 \%$, respectively, while hemoglobin levels were missing for 7 patients (1.1\%). Clinical characteristics of ART-naive patients, stratified according to anemia category are presented in Table 1. Most ART-naive patients presented with advanced HIV infection or AIDS; $66.7 \%$ had a CD4-cell count below 200 cells $/ \mathrm{mm}^{3}$, and $62.8 \%$ were in WHO stage III/IV. Malnourishment, defined as a body mass index (BMI) below $18.5 \mathrm{~kg} / \mathrm{m}^{2}$ was found in $38.0 \%$ of patients; severe

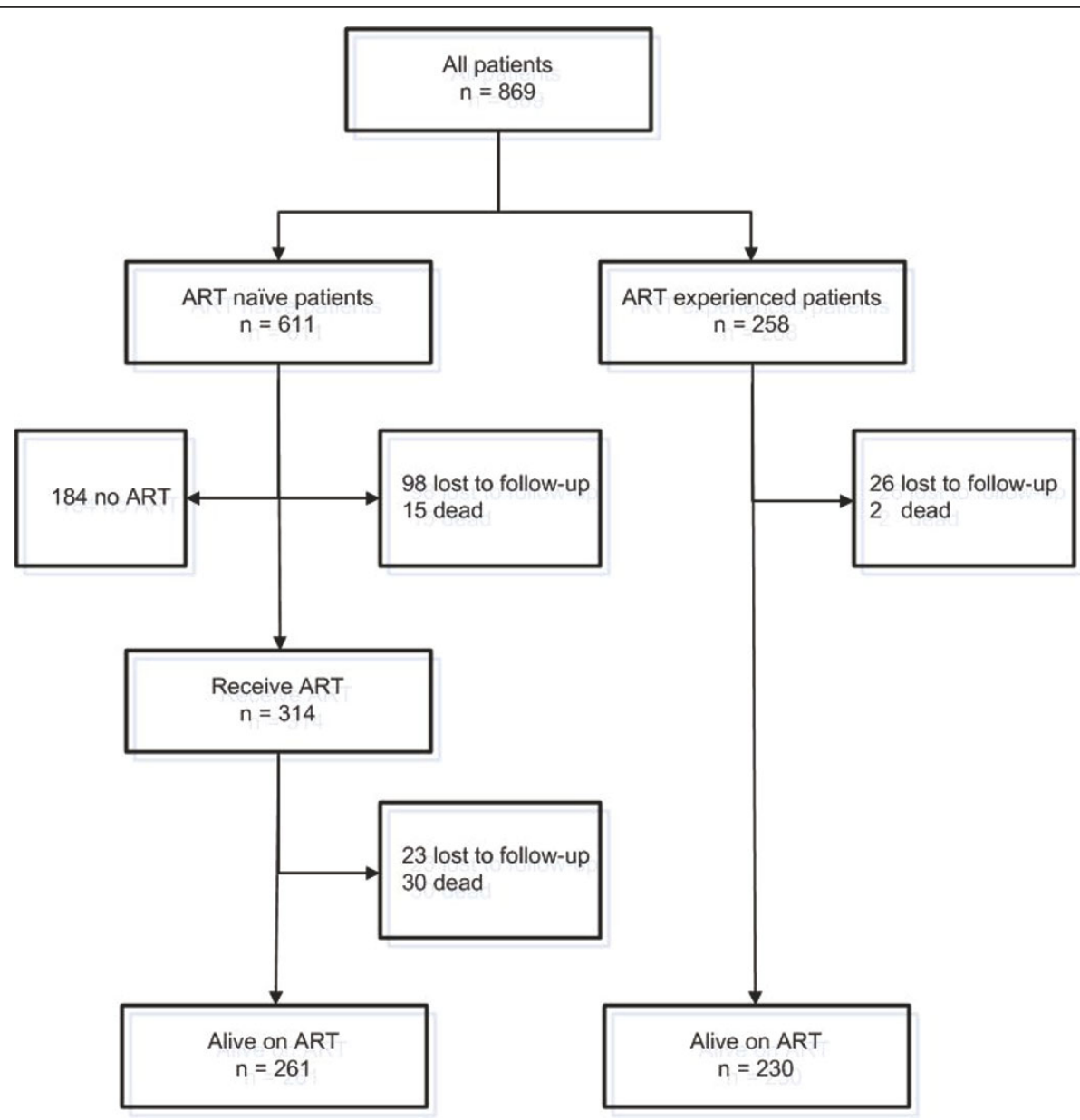

Figure 1 Follow-up diagram of the cohort HIV-patients in Hasan Sadikin Hospital Bandung, September 2007-August 2009 ( $n=869$ ) 
Table 1 Characteristics of ART-naïve and experienced HIV-patients in Hasan Sadikin Hospital, September 2007 August 2009 ( $n=869$ )

\begin{tabular}{|c|c|c|c|c|c|c|c|c|c|}
\hline \multirow[t]{2}{*}{ Characteristics } & \multicolumn{4}{|c|}{ ART naïve } & \multicolumn{4}{|c|}{ ART experienced } & \multirow{2}{*}{$\begin{array}{c}p \\
\text { value }\end{array}$} \\
\hline & $\begin{array}{c}\text { Total } \\
\mathrm{n}=611\end{array}$ & $\begin{array}{c}\text { No } \\
\text { anemia } \\
\mathrm{n}=304\end{array}$ & $\begin{array}{c}\text { Mild } \\
n=186\end{array}$ & $\begin{array}{c}\text { Moderate- } \\
\text { severe } \\
n=114\end{array}$ & $\begin{array}{c}\text { Total } \\
n=258\end{array}$ & $\begin{array}{c}\text { No } \\
\text { anemia } \\
n=216\end{array}$ & $\begin{array}{c}\text { Mild } \\
\mathrm{n}=37\end{array}$ & $\begin{array}{l}\text { Moderate- } \\
\text { severe } \\
n=5\end{array}$ & \\
\hline Male sex, \% & 68.2 & 67.1 & 68.8 & 69.3 & 81.6 & 83.6 & 73.0 & 60.0 & $<0.001$ \\
\hline Median age, yrs (IQR) & $28(26-31)$ & $28(25-30)$ & $29(26-32)$ & $29(26-34)$ & $29(26-32)$ & $29(26-32)$ & $30(26-34)$ & $31(29-31)$ & 0.45 \\
\hline $\begin{array}{l}\text { Median } \mathrm{BMI}, \mathrm{kg} / \mathrm{m}^{2} \\
(\mathrm{IQR})\end{array}$ & $\begin{array}{c}19.5 \\
(17.3-22.0)\end{array}$ & $\begin{array}{c}19.8 \\
(17.8-22.6)\end{array}$ & $\begin{array}{c}19.1 \\
(16.9-21.6)\end{array}$ & $\begin{array}{c}19.6 \\
(16.8-21.8)\end{array}$ & $\begin{array}{c}20.3 \\
(18.6-22.5)\end{array}$ & $\begin{array}{c}20.4 \\
(18.5-22.5)\end{array}$ & $\begin{array}{c}20.2 \\
(18.5-22.3)\end{array}$ & $\begin{array}{c}17.8 \\
(15.7-22.1)\end{array}$ & 0.63 \\
\hline History of IDU, \% & 63.1 & 64.9 & 61.8 & 61.0 & 84.4 & 86.5 & 78.4 & 40.0 & $<0.001$ \\
\hline Anti HCV (+), \% & 58.5 & 59.6 & 61.3 & 50.0 & 80.0 & 84.0 & 64.7 & 25.0 & $<0.001$ \\
\hline $\begin{array}{l}\text { Median CD4, cells/ } \\
\mathrm{mm}^{3} \\
(\mathrm{IQR})\end{array}$ & $\begin{array}{c}76 \\
(20-305)\end{array}$ & $\begin{array}{c}232 \\
(66-406)\end{array}$ & $\begin{array}{c}45 \\
(15-144)\end{array}$ & $\begin{array}{c}17 \\
(6-45)\end{array}$ & $\begin{array}{c}272 \\
(201-395)\end{array}$ & $\begin{array}{c}280 \\
(220-425)\end{array}$ & $\begin{array}{c}195 \\
(128-314)\end{array}$ & $\begin{array}{c}190 \\
(72-375)\end{array}$ & $<0.001$ \\
\hline TB treatment, \% & 21.3 & 6.3 & 27.4 & 50.9 & 3.9 & 2.8 & 5.4 & 40.0 & $<0.001$ \\
\hline Oral Candidiasis, \% & 27.8 & 21.8 & 35.4 & 31.4 & 3.3 & 2.0 & 5.7 & 40.0 & $<0.001$ \\
\hline Median MCV (IQR) (fl) & $\begin{array}{c}84.3 \\
(80.3-87.5)\end{array}$ & $\begin{array}{c}85.8 \\
(82.8-88.6)\end{array}$ & $\begin{array}{c}82.8 \\
(77.6-86.4)\end{array}$ & $\begin{array}{c}81.3 \\
(76.0-84.7)\end{array}$ & $\begin{array}{c}108.5 \\
(103.0-114.0)\end{array}$ & $\begin{array}{c}109.0 \\
(104.0- \\
114.0)\end{array}$ & $\begin{array}{c}108.0 \\
(99.8-114.0)\end{array}$ & $\begin{array}{c}88.4 \\
(81.0-100.1)\end{array}$ & $<0.001$ \\
\hline $\begin{array}{l}\text { Median MCH (IQR) } \\
(\mathrm{pg})\end{array}$ & $\begin{array}{c}28.9 \\
(27.3-30.2)\end{array}$ & $\begin{array}{c}29.5 \\
(28.2-30.5)\end{array}$ & $\begin{array}{c}28.4 \\
(25.9-29.8)\end{array}$ & $\begin{array}{c}27.8 \\
(25.7-29.2)\end{array}$ & $\begin{array}{c}38.4 \\
(36.0-40.6)\end{array}$ & $\begin{array}{c}38.4 \\
36.3-40.7)\end{array}$ & $\begin{array}{c}39.0 \\
(34.2-40.5)\end{array}$ & $\begin{array}{c}29.2 \\
(27.7-33.8)\end{array}$ & 0.58 \\
\hline $\begin{array}{l}\text { Reticulocyte index } \\
(\%)\end{array}$ & $\begin{array}{c}0.8 \\
(0.6-1.5)\end{array}$ & $\begin{array}{c}1.0 \\
(0.6-1.8)\end{array}$ & $\begin{array}{c}0.8 \\
(0.6-1.0)\end{array}$ & $1.0(0.5-2.7)$ & $0.8(0.6-1.0)$ & $0.9(0.7-1.4)$ & $0.6(0.5-1.0)$ & $1.0(1.0-1.0)$ & 0.02 \\
\hline
\end{tabular}

* $\mathrm{p}$ value for difference between ART-naïve and experienced group

Mild anemia: Hb 10.5 - $12.99 \mathrm{~g} / \mathrm{dL}$ for men; and 10.5 - $11.99 \mathrm{~g} / \mathrm{dL}$ for women, moderate-severe anemia: $\mathrm{Hb}<10.5 \mathrm{~g} / \mathrm{dL}$.

TB treatment: receive TB treatment in presentation or within 3 months of presentation

Anemia status missing in 7 patients, gender in 3 patients, age in 1 patients, BMI in 151 patients, IDU status in 46 patients, anti HCV in 117 patients, CD4 in 13 patients, oral candidiasis in 94 patients, reticulocyte index only available from 184 patients

BMI: body mass index; IDU: injecting drug user; HCV: Hepatitis C virus; TB: tuberculosis; MCV: mean corpuscular volume; MCH: mean corpuscular hemoglobin; IQR: interquartile range.

malnourishment $\left(\mathrm{BMI}<16 \mathrm{~kg} / \mathrm{m}^{2}\right)$ was found in $12.7 \%$ of patients. One fifth $(21.3 \%)$ of patients were already on TB treatment or started TB treatment within 3 months of presentation, $58.5 \%$ were co-infected with $\mathrm{HCV}$, and oral candidiasis was diagnosed in $27.8 \%$ of patients.

Anemia in ART-naïve HIV patients was mostly normocytic, normochromic and characterized by a normal or low reticulocyte index suggesting 'anemia of chronic disease' as the main cause. Anemia was associated with a low CD4-cell count ( $\mathrm{p}<0.001)$, and TB treatment ( $\mathrm{p}$ $<0.001$ ) (Table 1). Hepatitis C co-infection prevalence was not different in patients with and without anemia (56.9\% vs. $59.6 \%, \mathrm{p}=0.54)$. During follow-up, 314 patients $(51.4 \%)$ started ART after a median of 28 days (IQR: 19-55). The majority of patients (70.1\%), none of whom had moderate or severe anemia, were started on a ZDV-containing regimen. From this group, 13.6\% developed anemia during follow-up and were subsequently switched from ZDV to d4T.

\section{Mortality in ART-naïve patients}

Anemia was associated with increased mortality during follow-up. When 611 ART-naïve patients were followed for a median of 4.4 (IQR: 0.0-12.1) months (total follow- up: 335 person-years), 45 patients (7.4\%, IQR: 5.3\%9.5\%) died and 121 (19.8\%, IQR: 16.6\%-23.0\%) were lost to follow-up (Figure 1). Mortality (75.6\% of the total) and loss to follow-up (92.6\% of the total) were highest in the first 6 months after presentation. Using KaplanMeier estimates, the survival rates at 6 months were 98.6\% (95\% CI: 97.3-99.9\%) for patients without anemia, 95.1\% (92.0-98.5\%) for patients with mild anemia and $82.5 \%$ (75.5-89.4\%) for patients with moderate or severe anemia $(P<0.001$; Figure 2$)$. Beside a CD4 cell count below $50 / \mathrm{mm}^{3}$ (HR: 5.7, IQR: 1.6-17.8, $\mathrm{p}=0.003$ ), $\bmod -$ erate to severe anemia remained independently associated with an increased risk of death in multivariate analysis (HR: 6.5, IQR: 2.0-21.2, p = 0.002) (Table 2), This association remained significant after eliminating subjects with tuberculosis co-infection, which is an important risk factor for death.

\section{Iron status parameters in ART-naïve patients}

Serum ferritin, sTfR, CRP and reticulocyte index were measured in a subgroup of 141 randomly selected patients. ART-naïve patients $(\mathrm{n}=95)$ with available iron parameters had very high plasma ferritin concentrations (median $641 \mathrm{ng} / \mathrm{mL}$, IQR: 242-1296), moderately 


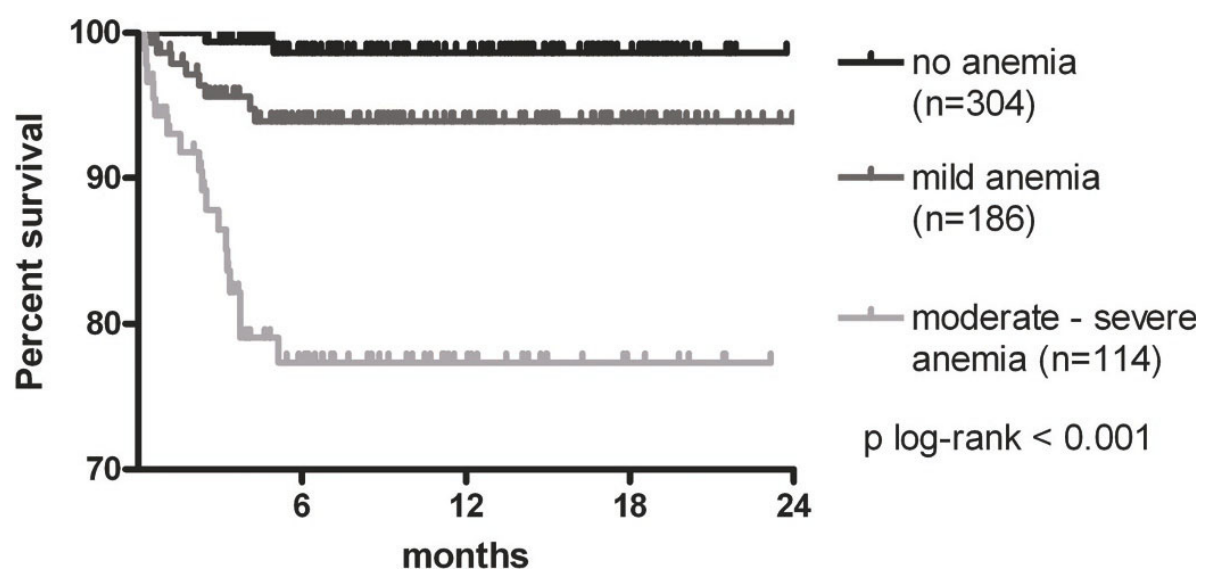

Figure 2 Kaplan-Meier survival curve for ART-naïve HIV-infected patients with no (black), mild (dark grey) or moderate/severe anemia (light grey) $(n=604)$.

elevated CRP concentrations (median $6 \mathrm{mg} / \mathrm{mL}$, IQR: 234), low sTfR concentrations (median $1014 \mathrm{U} / \mathrm{mL}$, IQR: 736-1322), and normal reticulocyte counts (median 0.8\%, IQR: $0.6-1.5 \%)$.
Very high ferritin concentrations were found in subjects with CD4 counts below or equal to 50 cells $/ \mathrm{mm}^{3}$ (median $1078 \mathrm{mg} / \mathrm{ml}$, IQR: 550-1824) compared to subjects with CD4 counts above 50 cells $/ \mathrm{mm}^{3}$ (median 279

Table 2 Multivariate analysis for factors related to six-month mortality among ART-naïve patients $(n=611)$ in Hasan Sadikin Hospital, September 2007 - August 2009

\begin{tabular}{|c|c|c|c|c|c|c|c|c|}
\hline & \multirow{3}{*}{$\mathrm{n}$} & \multirow{3}{*}{ Mortality } & \multicolumn{4}{|c|}{ Base Analysis } & \multirow{2}{*}{\multicolumn{2}{|c|}{$\begin{array}{c}\text { Sensitivity Analysis } \\
\text { Multivariate }\end{array}$}} \\
\hline & & & \multicolumn{2}{|c|}{ Univariate } & \multicolumn{2}{|l|}{ Multivariate } & & \\
\hline & & & HR (95\% Cl) & $p$ value & HR adjusted $(95 \% \mathrm{Cl})$ & $p$ value & HR adjusted $(95 \% \mathrm{CI})$ & $p$ value \\
\hline \multicolumn{9}{|l|}{ Gender } \\
\hline Female & 194 & 5 & 1 & & 1 & & 1 & \\
\hline Male & 416 & 29 & $2.8(1.1-7.4)$ & 0.03 & $1.5(0.5-4.3)$ & 0.46 & $1.8(0.5-6.2)$ & 0.32 \\
\hline \multicolumn{9}{|l|}{ Age (years old) } \\
\hline$<29$ & 317 & 11 & 1 & & 1 & & 1 & \\
\hline$\geq 29$ & 294 & 23 & $2.3(1.1-4.9)$ & 0.02 & $1.6(0.7-3.5)$ & 0.24 & $1.4(0.5-6.2)$ & 0.49 \\
\hline \multicolumn{9}{|l|}{ CD4 (cells/mL) } \\
\hline$>50$ & 353 & 4 & 1 & & 1 & & 1 & \\
\hline$\leq 50$ & 248 & 29 & $11.6(4.0-33.3)$ & $<0.001$ & $5.7(1.8-17.8)$ & 0.003 & $6.1(1.6-23.1)$ & 0.008 \\
\hline \multicolumn{9}{|l|}{$\mathrm{BMI}\left(\mathrm{kg} / \mathrm{m}^{2}\right)$} \\
\hline$\geq 18.5$ & 183 & 9 & 1 & & & & & \\
\hline$<18.5$ & 299 & 13 & $1.1(0.5-2.7)$ & 0.77 & & & & \\
\hline \multicolumn{9}{|l|}{ Anemia, (\%) } \\
\hline No anemia & 304 & 4 & 1 & & 1 & & 1 & \\
\hline Mild & 186 & 10 & $3.8(1.2-12.6)$ & 0.03 & $2.2(0.6-7.6)$ & 0.21 & $2.6(0.6-11.1)$ & 0.19 \\
\hline Moderate and severe & 114 & 20 & $16.0(5.3-47.9)$ & $<0.001$ & $6.5(2.0-21.2)$ & 0.002 & $10.9(2.7-44.3)$ & 0.001 \\
\hline \multicolumn{9}{|l|}{ History of IDU, (\%) } \\
\hline No & 209 & 11 & 1 & & & & & \\
\hline Yes & 357 & 21 & $1.1(0.5-2.4)$ & 0.76 & & & & \\
\hline \multicolumn{9}{|l|}{ ART, (\%) } \\
\hline No & 324 & 14 & 1 & & & & & \\
\hline Yes & 287 & 20 & $1.7(0.8-3.3)$ & 0.12 & & & & \\
\hline
\end{tabular}

*Data were missing for gender $(n=1), C D 4(n=10)$, BMI in 482 patients $(n=129)$, anemia status $(n=7)$, history of IDU ( $n=45)$.

Sensitivity analysis: subjects with TB treatment within 3 months presentation excluded from analysis

Mild anemia: Hb 10.5 - $12.99 \mathrm{~g} / \mathrm{dL}$ for men; and $10.5-11.99 \mathrm{~g} / \mathrm{dL}$ for women, moderate-severe anemia: $\mathrm{Hb}<10.5 \mathrm{~g} / \mathrm{dL}$.

ART: receive ART within 6 of presentation.

BMI, body mass index; IDU: injecting drug user; ART, anti retroviral; HR, hazard ratio; 
$\mathrm{mg} / \mathrm{ml}$, IQR: 41-465, $\mathrm{p}<0.001)$, and in subjects with moderate-severe anemia (median $1223 \mathrm{mg} / \mathrm{ml}$, IQR: 519-2764) compared to subjects without (median 436 mg/ml, IQR: 245-1296. $\mathrm{p}=0.07$ ) or with mild anemia (median $532 \mathrm{mg} / \mathrm{ml}$, IQR: 194-1099, p = 0.01). Moderately elevated hsCRP levels were also found in subjects with CD4 counts below or equal to 50 cells $/ \mathrm{mm}^{3}$ (median $12.2 \mathrm{mg} / \mathrm{L}$, IQR: 2.0-63.2) compared to subjects with CD4 counts above 50 cells $/ \mathrm{mm}^{3}$ (median $4.9 \mathrm{mg} / \mathrm{ml}$, IQR: $1.5-17.2, \mathrm{p}=0.08)$, and in subjects with moderatesevere anemia (median $18.4 \mathrm{mg} / \mathrm{ml}$, IQR 4.5-94.4) compared to subjects without (median $2.0 \mathrm{mg} / \mathrm{ml}$, IQR: 1.4$5.4, \mathrm{p}=0.001$ ) or with mild anemia (median $6.0 \mathrm{mg} / \mathrm{ml}$, IQR: 1.2-27.8, $\mathrm{p}=0.03)$. Subjects with high ferritin, high hsCRP or low sTfR concentrations showed a higher mortality during follow-up, although this was not statistically significant (Table 3$)$. Low ferritin levels $(<30 \mathrm{mg} /$ $\mathrm{ml}$ ) were found in $6.3 \%$ of patients, all were women with a CD4 cell count above 200 cells $/ \mathrm{mm}^{3}$. There was a significant negative correlation between ferritin concentrations and CD4 count (Figure 3).

Predictors of hyperferritinemia in ART-naïve patients were subsequently determined in a univariate and multivariate model (Table 4). CD4 cell count below $50 / \mathrm{mm}^{3}$ and hsCRP > $5 \mathrm{mg} / \mathrm{L}$ were associated with hyperferritinemia after correction for gender, degree of anemia, and $\mathrm{HCV}$ co-infection. After exclusion of patients with tuberculosis co-infection, low CD4 count was the only factor associated with hyperferritinemia.

\section{ART experienced patients}

At time of enrollment in the cohort, 258 patients were already taking $1^{\text {st }}$ line ART, for a median of 24.0 months (range: 3.3 - 96.3 months). The majority of patients were on a $\mathrm{ZDV}$ containing regimens $(62.8 \%)$, the others on a

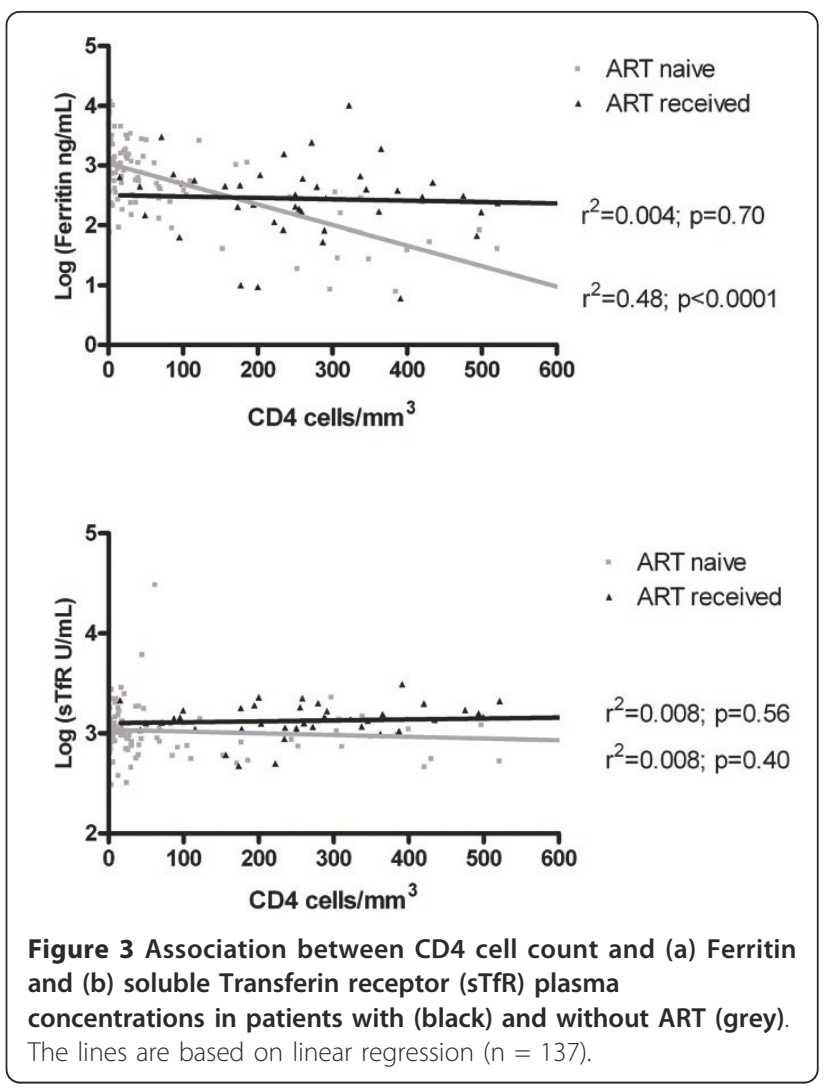

$\mathrm{d} 4 \mathrm{~T}$ containing regimen. Anemia was less common in patients taking ART: $14.3 \%$ had mild, $1.9 \%$ had moderate, and no patient had severe anemia $(\mathrm{p}<0.001)$ (Table 1 ). The use of ZDV was associated with anemia: among patients taking ZDV, 20.3\% had anemia, compared with $7.4 \%$ among those who were not taking ZDV ( $\mathrm{p}=0.01)$. During a median 19.8 months (IQR: 9.8-20.0), 2 (0.8\%)

Table 3 Associations between iron and inflammatory parameters and mortality among ART-naïve patients $(n=95)$ in Hasan Sadikin Hospital, September 2007 - August 2009

\begin{tabular}{|c|c|c|c|c|c|c|}
\hline & \multirow[b]{2}{*}{$\mathrm{n}$} & \multirow[b]{2}{*}{ mortality } & \multicolumn{2}{|c|}{ Single } & \multicolumn{2}{|c|}{ Multiple* } \\
\hline & & & HR (95\% Cl) & $p$ value & HR $(95 \% \mathrm{Cl})$ & $p$ value \\
\hline \multicolumn{7}{|l|}{ Ferritin } \\
\hline Low-normal & 31 & 4 & 1 & & 1 & \\
\hline High & 64 & 16 & $1.8(0.6-5.4)$ & 0.29 & $1.3(0.4-4.6)$ & 0.68 \\
\hline \multicolumn{7}{|l|}{ sTfR } \\
\hline Normal-high & 10 & 4 & 1 & & 1 & \\
\hline Low & 85 & 16 & $2.2(0.7-6.6)$ & 0.16 & $1.7(0.5-5.3)$ & 0.38 \\
\hline \multicolumn{7}{|l|}{ hsCRP } \\
\hline$<50 \mathrm{mg} / \mathrm{L}$ & 41 & 5 & 1 & & 1 & \\
\hline$>50 \mathrm{mg} / \mathrm{L}$ & 54 & 15 & $2.2(0.1-6.1)$ & 0.12 & $2.1(0.6-7.3)$ & 0.24 \\
\hline
\end{tabular}

${ }^{*}$ Cox proportional hazard models adjusted for CD4 cell count $\left(<50,>50\right.$ cells $\left./ \mathrm{mm}^{3}\right)$, age $(<29,>29$ years old), anemia (no anemia $\mathrm{Hb}>13 \mathrm{~g} / \mathrm{dl}$ for men and $>$ $12 \mathrm{~g} / \mathrm{dl}$ for women, mild $\mathrm{Hb}<10.5-12.99 \mathrm{~g} / \mathrm{dL}$ for men; and < $10.5-11.99 \mathrm{~g} / \mathrm{dL}$ for women, moderate-severe anemia: $\mathrm{Hb}<10.5 \mathrm{~g} / \mathrm{dL}$ ), and gender. Ferritin: High > $400 \mathrm{ng} / \mathrm{mL}$ for men or $>150 \mathrm{ng} / \mathrm{mL}$ for women, low-normal < $400 \mathrm{ng} / \mathrm{mL}$ for men or $<150 \mathrm{ng} / \mathrm{mL}$ for women; sTfR: Low < 1870 U/mL; normalhigh $>1870 \mathrm{U} / \mathrm{mL}$

$\mathrm{HR}$, Hazard ration; $\mathrm{Cl}$ : confidence interval; hsCRP, high sensitive C-reactive protein. 
Table 4 Multivariate analysis for factors related to high-ferritin concentrations among ART-naïve patients ( $n=95$ ) in Hasan Sadikin Hospital, September 2007 - August 2009

\begin{tabular}{|c|c|c|c|c|c|c|c|c|}
\hline & \multirow{3}{*}{$\mathrm{n}$} & \multirow{3}{*}{ high ferritin } & \multicolumn{4}{|c|}{ Base analysis } & \multirow{2}{*}{\multicolumn{2}{|c|}{$\begin{array}{c}\text { Sensitivity analysis } \\
\text { Multivariate }\end{array}$}} \\
\hline & & & \multicolumn{2}{|c|}{ Univariate } & \multicolumn{2}{|c|}{ Multivariate } & & \\
\hline & & & $\begin{array}{c}\text { OR } \\
(95 \% \mathrm{Cl}) \\
\end{array}$ & $p$ value & $\begin{array}{c}\text { OR adjusted } \\
(95 \% \mathrm{Cl})\end{array}$ & $p$ value & OR adjusted $(95 \% \mathrm{Cl})$ & $p$ value \\
\hline \multicolumn{9}{|l|}{ Gender } \\
\hline Female & 27 & 12 & 1 & & 1 & & 1 & \\
\hline Male & 68 & 52 & $4.1(1.6-10.4)$ & 0.004 & $1.5(0.5-5.1)$ & 0.47 & $1.8(0.50-6.2)$ & 0.39 \\
\hline \multicolumn{9}{|l|}{ Anemia } \\
\hline No anemia & 15 & 10 & 1 & & & & & \\
\hline Mild & 56 & 35 & $0.8(0.3-2.8)$ & 0.77 & & & & \\
\hline Moderate - severe & 24 & 19 & $1.9(0.4-8.2)$ & 0.39 & & & & \\
\hline \multicolumn{9}{|l|}{ hsCRP (mg/L) } \\
\hline$<5$ & 41 & 21 & 1 & & 1 & & 1 & \\
\hline$>5$ & 54 & 43 & $3.7(1.5-9.2)$ & 0.004 & $3.8(1.3-10.9)$ & 0.01 & $2.8(0.9-8.4)$ & 0.07 \\
\hline \multicolumn{9}{|l|}{ CD4 (cells/mL) } \\
\hline$>50$ & 33 & 12 & 1 & & 1 & & 1 & \\
\hline $0-50$ & 60 & 51 & $9.9(3.6-27.0)$ & $<0.001$ & $10.0(3.5-28.8)$ & $<0.001$ & $6.8(2.2-20.3)$ & 0.001 \\
\hline \multicolumn{9}{|l|}{ Anti HCV } \\
\hline Negative & 19 & 9 & 1 & & & & & \\
\hline Positive & 36 & 25 & $2.5(0.8-7.9)$ & 0.11 & & & & \\
\hline
\end{tabular}

${ }^{*}$ CD4 cell counts were missing in 2 patients, HCV serostatus in 40 patients.

Sensitivity analysis: subjects with TB treatment within 3 months presentation excluded from analysis

High ferritin: > $400 \mathrm{ng} / \mathrm{mL}$ for men or $>150 \mathrm{ng} / \mathrm{mL}$ for women

Mild anemia: $\mathrm{Hb} 10.5$ - $12.99 \mathrm{~g} / \mathrm{dL}$ for men; and 10.5 - $11.99 \mathrm{~g} / \mathrm{dL}$ for women, moderate-severe anemia: $\mathrm{Hb}<10.5 \mathrm{~g} / \mathrm{dL}$.

ART, anti retroviral; OR, odd ratio; hsCRP, high sensitive C-reactive protein; $\mathrm{HCV}$, hepatitis virus C.

ART experienced patients died and 26 (10.1\%) were lost to follow-up.

Patients taking ART seemed to have lower plasma ferritin concentrations (median $304.1 \mathrm{ng} / \mathrm{mL}$, IQR; $160.7-$ 574.6) compared to ART-naïve patients, although this was not statistically significant $(\mathrm{p}=0.12)$. In addition, they had lower hsCRP values (median $3.0 \mathrm{mg} / \mathrm{mL}$, IQR: 0.9-6.3, $\mathrm{p}=0.02$ ), but similarly low sTfR concentrations (median 1378.5 U/mL, IQR: 1104.3-1798.5, $\mathrm{p}=0.95$ ) compared to ART-naïve patients. Duration of ART was not associated with plasma concentrations of ferritin or sTfR (data not shown). There was a significant negative correlation between ferritin concentrations and CD4 count in ART-naïve patients, but not in patients taking ART (Figure 3).

\section{Discussion}

The results from our study indicate that anemia is highly prevalent among HIV patients in Indonesia and that moderate to severe anemia is strongly related to mortality. This is in line with findings from other studies [2,3,30-32]. We also report serum concentrations of ferritin and sTfR, both of which are often used for assessment of iron status. High serum ferritin concentrations were found, especially in patients with CD4 cell counts below 200 cells $/ \mathrm{mm}^{3}$. Iron redistribution in the setting of a prolonged acute phase response is most likely responsible for this observation and this may explain the reported iron excess in the liver, bone marrow and other organs during the advanced stages of HIV [33]. Concentrations of CRP were however only moderately elevated and did not correlate well with ferritin concentrations. Although CRP is the most commonly used indicator of inflammation in daily practice, other acute phase response proteins such as a-1-acidglycoprotein (AGP) may better reflect serum ferritin changes in inflammation because AGP remains elevated for a much longer time in sub-clinical chronic infections compared to CRP $[15,34]$.

We found that sTfR concentrations were generally low and not related to CD4 count. This finding is in contrast to studies that showed that sTfR is not affected by HIV infection, even though these studies also report that sTfR alone has little value for differentiating anemia in the presence of inflammation [12,35,36]. We hypothesize that low sTfR concentrations more likely reflects the presence of some degree of bone marrow suppression by HIV. Together, these findings suggest that both serum ferritin and sTfR concentrations may not be reliable indicators of iron status in advanced HIV infection.

The prevalence of anemia was more than $40 \%$ in our untreated HIV-infected patients, more or less similar to 
studies from outside Indonesia [2,18,30,37]. Severe anemia was noticed in nearly $5 \%$ of our patients and this was higher compared to previous data from Europe [2] or Asia [3] but lower compared to a study from Africa [30]. Differences between the levels of immunodeficiency in the different studies may account for these differences. Our study also demonstrates that anemia is strongly related to increased mortality, as reported by others $[2,3,30,31]$. Interestingly, we found that this was also true after correction for CD4 cell count, indicating that anemia is an independent factor for HIV disease progression.

Measurement of iron parameters in a sub-group of patients revealed marked elevations in plasma ferritin, in line with earlier studies [14,17-19,35]. Our study shows that high ferritin levels are strongly (and inversely) related to $\mathrm{CD} 4$ cell numbers but not to gender, HCV co-infection nor CRP as a marker of inflammation, as has been suggested by others $[19,37]$. Apart from the prolonged acute phase response, the inverse relation between ferritin and CD4 cell count may also be caused by increased oxidative stress [38] related to depletion of CD4 cells [39]. Furthermore, The HIV virus itself may increase ferritin levels as HIV-1 Nef protein directly down-regulates the hemochromatosis protein HFE and as such causes iron accumulation [40]. However, the latter hypothesis was not supported by a study among HIV patients in Thailand, which reported no relation between serum ferritin concentrations and plasma HIV RNA [20]. Finally, the role of inflammation cannot be completely excluded since inflammatory pathways that do not include IL-6 and CRP can lead to high ferritin concentrations [41]. Interestingly, the inverse relation between ferritin levels and CD4 cell numbers disappeared after ART. This could be due to the effect of ART on oxidative stress, plasma HIV-RNA and/or inflammation. Our results argue against an important role of $\mathrm{HCV}$ as no relation was found between ferritin and $\mathrm{HCV}$ infection, although the number of subjects in whom all parameters were measured was limited.

Low ferritin levels $(<30 \mathrm{mg} / \mathrm{ml})$ indicating iron deficiency were found in $6.3 \%$ of our patients and in $18.5 \%$ of the female patients. In previous studies from United States, iron deficiency anemia was found in $20 \%$ of HIV infected female injecting drug users [42], and iron supplementation was found to reduce anemia without adverse effects on HCV co-infection or plasma HIVRNA [43]. However, iron supplementation should be done carefully and only in patients with iron deficiency as iron overload is associated with a poor prognosis of HIV-1 and hepatitis $C$ virus infections and with growth of pathogenic microorganism [7]. Indeed, excess mortality was reported among HIV-infected patients receiving low-dose oral iron with dapsone for Pneumocystis carinii pneumonia prophylaxis [11]. In our study, we did not find a significant relation between plasma ferritin level and mortality, even though those who died on average had two-fold higher plasma ferritin levels.

Unlike ferritin, sTfR levels showed no association with CD4 cell counts, neither among ART-naïve nor among ART-experienced patients. Furthermore, sTfR levels were not different in anemic versus non-anemic subjects. Our sTfR levels seem slightly low, especially in ART-naïve patients suggesting that reduced erythropoiesis may contribute to the development of anemia, although no relation was found between STfR levels and the presence or degree of anemia. Plasma sTfR concentrations were not associated with mortality during follow-up. This was also found in other studies which showed an increase of sTfR following ART [19,21], and no relation between STfR levels and disease progression [19].

Our study has several limitations as it was observational, and as iron parameters were only measured in a subset of patients. Furthermore, no data are available on food or micronutrient intake which might affect iron status, and on occurrence of other opportunistic infections causing anemia. Tuberculosis could be important cause of anemia and could confound the results, although sensitivity analysis showed this was not the case. Furthermore we did not adjust ferritin concentrations for circulating HIV-RNA which are not measured routinely in ART-naïve patients. To be able to see the effects of ART on iron parameters, we excluded nonadherent patients. Loss to follow-up may have affected the estimated mortality, although we believe this did not affect our conclusions, since there was no significant difference in clinical characteristics including degree of anemia and CD4 cell count between patients with and without follow-up (data not shown).

\section{Conclusion}

We can conclude that anemia, although usually mild, is highly prevalent in this setting and strongly related to immune-deficiency and mortality. Iron maldistribution and not iron deficiency seems to underlie the development of anemia while the role of compromised erythropoiesis and HCV co-infection seems limited.

\section{Acknowledgements}

We would like to thank Director of Hasan Sadikin General Hospital and Dean of the Medical Faculty Padjadjaran University for encouraging and accommodating research in their institutions.

This study was supported by 'IMPACT' (Integrated Management of Prevention And Care and Treatment of HIV/AIDS), a collaborative research and implementation program of Padjadjaran University, Bandung, Indonesia; Maastricht University and Radboud University Nijmegen, the Netherlands; and Antwerpen University, Belgium. IMPACT is funded by the European Commission (SANTE/2005/105-033) 


\section{Author details}

'Department of Internal Medicine Faculty of Medicine, Padjadjaran University/Hasan Sadikin Hospital, Bandung, Indonesia. ${ }^{2}$ Health Research Unit, Faculty of Medicine, Padjadjaran University, Bandung, Indonesia. ${ }^{3}$ Clinical Pathology Faculty of Medicine, Padjadjaran University/Hasan Sadikin Hospital, Bandung, Indonesia. ${ }^{4}$ Department of Internal Medicine, Radboud University Nijmegen Medical Centre, the Netherlands.

\section{Authors' contributions}

RW designed, performed statistical analysis and prepared the manuscript. RS, ARI and AZ, did laboratory examinations and help collected data. HJ, QdM, RvC and AvdV designed, gave advice on statistical analysis and prepared the manuscript. All authors read and approved the final manuscript.

\section{Competing interests}

The authors declare that they have no competing interests.

Received: 5 November 2010 Accepted: 9 August 2011

Published: 9 August 2011

\section{References}

1. Belperio PS, Rhew DC: Prevalence and outcomes of anemia in individuals with human immunodeficiency virus: a systematic review of the literature. Am J Med 2004, 116(Suppl 7A):27S-43S.

2. Lundgren JD, Mocroft A: Anemia and survival in human immunodeficiency virus. Clin Infect Dis 2003, 37(Suppl 4):S297-S303.

3. Srasuebkul P, Lim PL, Lee MP, Kumarasamy N, Zhou J, Sirisanthana T, Li PCK, Kamarulzaman A, Oka S, Phanuphak P, Vonthanak S, Merati TP, Chen YA, Sunkanuparph S, Tau G, Zhang F, Lee CKC, Diatngco R, Pujari S, Choi JY, Smith J, Law MG: Short-term clinical disease progression in HIV-infected patients receiving combination antiretroviral therapy: results from the TREAT Asia HIV observational database. Clin Infect Dis 2009, 48(7):940-50.

4. Volberding PA, Levine AM, Dieterich D, Mildvan D, Mitsuyasu R, Saag M: Anemia in HIV infection: clinical impact and evidence-based management strategies. Clin Infect Dis 2004, 38(10):1454-63.

5. Kreuzer KA, Rockstroh JK: Pathogenesis and pathophysiology of anemia in HIV infection. Ann Hematol 1997, 75(5-6):179-87.

6. Northrop-Clewes CA: Interpreting indicators of iron status during an acute phase response - lessons from malaria and human immunodeficiency virus. Ann Clin Biochem 2008, 45(Pt 1):18-32.

7. Drakesmith $H_{1}$ Prentice A: Viral infection and iron metabolism. Nat Rev Microbiol 2008, 6(7):541-52.

8. Ganz T: The role of hepcidin in iron sequestration during infections and in the pathogenesis of anemia of chronic disease. Isr Med Assoc J 2002, 4(11):1043-5.

9. Vyoral D, Petrak J: Hepcidin: a direct link between iron metabolism and immunity. Int J Biochem Cell Biol 2005, 37(9):1768-73.

10. Weiss G, Goodnough LT: Anemia of chronic disease. N Engl J Med 2005, 352(10):1011-23.

11. Gordeuk VR, Delanghe JR, Langlois MR, Boelaert JR: Iron status and the outcome of HIV infection: an overview. J Clin Virol 2001, 20(3):111-5.

12. Savarino A, Pescarmona GP, Boelaert JR: Iron metabolism and HIV infection: reciprocal interactions with potentially harmful consequences? Cell Biochem Funct 1999, 17(4):279-87.

13. Gordeuk VR, Onojobi G, Schneider MF, Dawkins MF, Delapenha R, Voloshin Y, von Wyi V, Bacon M, Minkoff H, Levine A, Cohen M, Greenblatt RM: The association of serum ferritin and transferrin receptor concentrations with mortality in women with human immunodeficiency virus infection. Haematologica 2006, 91(6):739-43.

14. McDermid JM, Jaye A, Schim van der Loeff MF, Todd J, Bates C, Austin S, Jeffries $D$, Awasana AA, Whittle HC, Prentice AM: Elevated iron status strongly predicts mortality in West African adults with HIV infection. J Acquir Immune Defic Syndr 2007, 46(4):498-507.

15. Joint World Health Organization/Centers for Disease Control and Prevention Technical Consultation on the Assessment of Iron Status at the Population Level: Assessing the Iron Status of Population: Report of a Joint World Health Organization/Centers for Disease Control and Prevention Technical Consultation on the Assessment of Iron Status at the Population Level. Malta: World Health Organization; 2005.

16. Beguin Y: Soluble transferrin receptor for the evaluation of erythropoiesis and iron status. Clin Chim Acta 2003, 329(1-2):9-22.
17. Mburu AS, Thurnham DI, Mwaniki DL, Muniu EM, Alumasa F, de Wagt A: The influence and benefits of controlling for inflammation on plasma ferritin and hemoglobin responses following a multi-micronutrient supplement in apparently healthy, HIV+ Kenyan adults. J Nutr 2008, 138(3):613-9.

18. Salome MA, Grotto HZ: Human immunodeficiency virus-related anemia of chronic disease: relationship to hematologic, immune, and iron metabolism parameters, and lack of association with serum interferongamma levels. AIDS Patient Care STDS 2002, 16(8):361-5.

19. Sarcletti M, Quirchmair G, Weiss G, Fuchs D, Zangerle R: Increase of haemoglobin levels by anti-retroviral therapy is associated with a decrease in immune activation. Eur J Haematol 2003, 70(1):17-25.

20. Boom J, Kosters E, Duncombe C, Kerr S, Hisrchel B, Ruxrungtham K, de Mast Q, Kosalaraksa P, Ulbolyam S, Jupimai T, Ananworanich J, the Staccato Study Group: Ferritin levels during structured treatment interruption of highly active antiretroviral therapy. HIV Med 2007, 8(6):388-95.

21. Costantini A, Giuliodoro S, Butini L, Silvestri G, Leoni P, Montroni M: Abnormalities of erythropoiesis during HIV-1 disease: a longitudinal analysis. J Acquir Immune Defic Syndr 2009, 52(1):70-4.

22. Girelli D, Pasino M, Goodnough JB, Nemeth E, Guido M, Castagna A, Busti F, Campostrini N, Martinelli N, Vantini I, Corrocher R, Ganz T, Fattovich G: Reduced serum hepcidin levels in patients with chronic hepatitis $C$. $J$ Hepatol 2009, 51(5):845-52

23. Wisaksana R, Indrati AK, Fibriani A, Rogayah E, Sudjana P, Djajakusumah TS, Sumantri R, Alisjahbana B, van der Ven A, van Crevel R: Response to firstline antiretroviral treatment among human immunodeficiency virusinfected patients with and without a history of injecting drug use in Indonesia. Addiction 2010, 105(6):1055-61.

24. Departemen Kesehatan Republik Indonesia: Pedoman nasional terapi antiretroviral. 2007.

25. World Health Organization: Antiretroviral Therapy for HIV infection in adults and adolescents in resources-limited settings: Toward Universal Access. Geneva; 2006, 68-71.

26. Greer JP, Foerster J, Lukens JN: Wintrobe's Clinical Hematology. 11 edition. Lippincot Williams \& Wilkins Publisher; 2003.

27. de Benoist B, McLean E, Egli I, Cogswell M: Worldwide prevalence of anaemia 1993-2005: WHO Global Database on Anaemia. Spain: World Health Organization; 2008.

28. Moyle G: Anaemia in persons with HIV infection: prognostic marker and contributor to morbidity. AIDS Rev 2002, 4(1):13-20.

29. Lidya, Rutherford M, Apriani L, Janssen W, Rahmadi A, Parwati I, Yuwono A, van Crevel R: Improving Diagnosis of Pulmonary Tuberculosis Among HIV/AIDS Patients: Literature Review and Experience in a Teaching Hospital in Indonesia. Acta Medica Indonesiana 2009, 41(Supplement 1):57-64.

30. McDermid JM, van der Loeff MF, Jaye A, Hennig BJ, Bates C, Todd J, Sirugo G, Hill AV, Whittle HC, Prentice AM: Mortality in HIV infection is independently predicted by host iron status and SLC11A1 and HP genotypes, with new evidence of a gene-nutrient interaction. Am J Clin Nutr 2009, 90(1):225-33.

31. Sullivan PS, Hanson DL, Chu SY, Jones JL, Ward JW: Epidemiology of anemia in human immunodeficiency virus (HIV)-infected persons: results from the multistate adult and adolescent spectrum of HIV disease surveillance project. Blood 1998, 91(1):301-8.

32. Kiragga AN, Castelnuovo B, Nakanjako D, Manabe YC: Baseline severe anaemia should not preclude use of zidovudine in antiretroviral-eligible patients in resource-limited settings. J Int AIDS Soc 2010, 13:42.

33. Boelaert JR, Weinberg GA, Weinberg ED: Altered iron metabolism in HIV infection: mechanisms, possible consequences, and proposals for management. Infect Agents Dis 1996, 5(1):36-46.

34. Rawat R, Stoltzfus RJ, Ntozini R, Mutasa K, liff PJ, Humphrey JH: Influence of inflammation as measured by alpha-1-acid glycoprotein on iron status indicators among HIV-positive postpartum Zimbabwean women. Eur J Clin Nutr 2009, 63(6):787-93.

35. Kupka R, Msamanga Gl, Mugusi F, Petraro P, Hunter DJ, Fawzi WW: Iron status is an important cause of anemia in HIV-infected Tanzanian women but is not related to accelerated HIV disease progression. J Nutr 2007, 137(10):2317-23.

36. Semba RD, Kumwenda N, Hoover DR, Taha TE, Mtimavalye L, Broadhead R, Eisinger W, Miotti PG, Chiphangwi JD: Assessment of iron status using plasma transferrin receptor in pregnant women with and without 
human immunodeficiency virus infection in Malawi. Eur J Clin Nutr 2000, 54(12):872-7.

37. Dikshit B, Wanchu A, Sachdeva RK, Sharma A, Das R: Profile of hematological abnormalities of Indian HIV infected individuals. BMC Blood Disord 2009, 9:5.

38. Koorts AM, Viljoen M: Ferritin and ferritin isoforms II: protection against uncontrolled cellular proliferation, oxidative damage and inflammatory processes. Arch Physiol Biochem 2007, 113(2):55-64.

39. Wanchu A, Rana SV, Pallikkuth S, Sachdeva RK: Short communication: oxidative stress in HIV-infected individuals: a cross-sectional study. AIDS Res Hum Retroviruses 2009, 25(12):1307-11.

40. Drakesmith H, Chen N, Ledermann H, Screaton G, Townsend A, Xu XN: HIV1 Nef down-regulates the hemochromatosis protein HFE, manipulating cellular iron homeostasis. Proc Natl Acad Sci USA 2005, 102(31):11017-22.

41. Torti FM, Torti SV: Regulation of ferritin genes and protein. Blood 2002, 99(10):3505-16.

42. Semba RD, Shah N, Klein RS, Mayer KH, Schuman P, Vlahov D: Prevalence and cumulative incidence of and risk factors for anemia in a multicenter cohort study of human immunodeficiency virus-infected and -uninfected women. Clin Infect Dis 2002, 34(2):260-6.

43. Semba RD, Ricketts EP, Mehta S, Netski D, Thomas D, Kirk G, Wu AW, Vlahov D: Effect of micronutrients and iron supplementation on hemoglobin, iron status, and plasma hepatitis C and HIV RNA levels in female injection drug users: a controlled clinical trial. J Acquir Immune Defic Syndr 2007, 45(3):298-303.

Pre-publication history

The pre-publication history for this paper can be accessed here: http://www.biomedcentral.com/1471-2334/11/213/prepub

doi:10.1186/1471-2334-11-213

Cite this article as: Wisaksana et al: Anemia and iron homeostasis in a cohort of HIV-infected patients in Indonesia. BMC Infectious Diseases 2011 $11: 213$.

\section{Submit your next manuscript to BioMed Central and take full advantage of:}

- Convenient online submission

- Thorough peer review

- No space constraints or color figure charges

- Immediate publication on acceptance

- Inclusion in PubMed, CAS, Scopus and Google Scholar

- Research which is freely available for redistribution

Submit your manuscript at www.biomedcentral.com/submit 